\title{
Evaluation of the sub-regional integration of the Greater Mekong Sub-region (GMS) and its effects on Thailand's domestic economy
}

\author{
Ngampramuan Soavapa \\ Ramkhamhaeng University, \\ 2086 Ramkhamhaeng Rd, Hua Mak, Bang Kapi District, Bangkok 10240, Bangkok, Thailand \\ Aoyama Gakuin University, \\ 4 Chome-4-25 Shibuya, Shibuya City, Tokyo 150-8366, Japan
}

For citation: Ngampramuan Soavapa. Evaluation of the sub-regional integration of the Greater Mekong Sub-region (GMS) and its effects on Thailand's domestic economy. Vestnik of Saint Petersburg University. International Relations, 2020, vol. 13, issue 1, pp. 96-110.

https://doi.org/10.21638/spbu06.2020.107

This paper aims to investigate the sub-regional integration dynamics exhibited in the Greater Mekong Sub-region (GMS) process and its impact on Thailand's economic development. Subregionalism assumes that sub-regional integration processes are based on geographic proximity, local business and governmental actors, and a shared historical and cultural awareness. The GMS includes Cambodia, China, Laos, Myanmar, Thailand and Vietnam, which have been engaged in this cooperation since 1992. Among these countries in Southeast Asia, Thailand has the largest economy, and it has a strong interest in supporting sub-regional integration with the GMS countries, because it includes Thai national economic development policy and government projects, which are also supported by Thailand's business sector. Indeed, there are clearly observable economic impacts, since Thailand's border regions profit from a growing trans-border economy between Thailand and the other GMS countries. This paper will examine how the GMS Strategic Framework (SF) II (2012-2018) relates to Thailand's development strategies and will analyse the implications with regard to economic corridor and transport development in the context of the 2012-2018 strategy. Such an enquiry is especially relevant considering that Thailand promotes the development of economic corridors and the facilitation of cross-border economic activities to link with neighbouring countries in terms of trade, investment, and tourism. However, by placing these developments in a contemporary historical context, we also have to evaluate Thailand's early approaches to sub-regional integration processes within the Mekong area.

Keywords: Asian sub-regionalism, Mekong Sub-region, Thailand economic development.

\section{Introduction}

This paper is part of a wider research project that makes a comparative evaluation of sub-regional integration processes in Europe and Asia. In particular, the focus is on subregional integration processes along the Danube and Mekong rivers, namely the European Union Strategy for the Danube Region (EUSDR) and the Greater Mekong Sub-region (GMS). In order to evaluate the development impact of these two sub-regional integration processes, a number of research interviews have been conducted in Austria, Brussels

(c) Санкт-Петербургский государственный университет, 2020 
(EU members), and Thailand. This research focus is also related to the announcements made at the $12^{\text {th }}$ Asia-Europe Minister Meeting in 2015, where the ministers encouraged cooperation in water-related issues through trans-boundary, sub-regional and bi-regional cooperation between the Mekong and Danube regions under the framework of the ASEM Sustainable Development Dialogue [1]. This paper focuses on the Thai case study and the GMS integration processes.

Thailand is by far the largest economy of the five GMS countries in ASEAN, and as such, Thai economic development has an important impact on the other economies within the GMS in terms of trade and investment. When the GMS was established, Thailand already had a highly market-oriented economy that mainly took the form of increasing trade and capital flow liberalisation, becoming a significant trading country for the subregion. Its markets have been open to foreign trade, though subject to moderate levels of tariff and non-tariff barriers. As far as the Thai government was concerned, there were a number of advantages to promoting the GMS process. These included the prospect of Thailand becoming the transportation hub of the sub-region and making additional gains from regional trade and tourism. The government and business community also saw an opportunity for developing its remote and border areas by actively participating in and supporting the GMS process. For these reasons, the Thai government became a strong promoter of the GMS Economic Corridor concept in order to establish land, water, air and railway infrastructural linkages with the GMS members, thus facilitating economic activities along its border area. Economic corridors such as the North-South Economic corridor, which links the northern part of Thailand with the province of Yunnan in China, and the East-West Economic Corridor, which links Thailand via Laos with Vietnam and with Mawlamying in Myanmar, are good examples of the positive sub-regional impact generated for Thailand's economy. This in turn convinced domestic actors, political and economic alike, even more to take an active role in the GMS integration process. This strong Thai involvement also supported the economic development of the other GMS countries and thus offered additional support for the whole sub-regional integration dynamic.

This paper is organised in the following way. It will start with a general assessment of the GMS process from its beginning in 1992 and include the current GMS strategic framework 2012-2022. This is followed by in-depth analysis of Thailand's involvement in the GMS process and the impact the sub-regional integration process had on Thailand's remote and border areas. Within this focus, there is also an evaluation of Thai domestic actors with regard to the sub-regional integration process.

\section{What is sub-regionalism?}

In general, regionalism is associated with institution-building, with a state-centric, top-down, process. It is considered a 'state-led project to reorganize a particular regional space along defined economic and political lines [2, p. 2]. The notion of region gained a new momentum in the 1990s, when the primary level of international affairs moved away from the traditional state unit. The central hypothesis of regionalism is that a limited number of states are linked together by a geographical area and share the same concerns, such as strategic, economic and ecological relationships, with a certain degree of mutual interdependence. Waltz [3] suggested that regionalism might be examined as a response to external challenges and therefore has much in common with the politics of alliance for- 
mation. Cooperation within the region will depend on the existence of international institutions or regimes, whose main contribution is that they change the context within which states make decisions. Regionalism also includes a strong deregulatory agenda among its members, associated directly with the regionalist scheme to generate efficiency gains.

While the prospect of creating additional economic growth through regional cooperation underlines regionalism, developments within the international system may also support regional integration processes. The end of the Cold War, leading to the end of the superpower competition between the United States and the Soviet Union, opened up political spaces for regional cooperation. The subsequent onset of economic globalization around the world generated pressure for regional coalitions in many locations. Economic regionalism is a project of governments responding to the need to improve regional competitiveness in global markets.

Regional integration processes based on the perceived need to respond to global economic changes are described as 'new regionalism', which is concerned with the liberalization of economic activities and export promotion. While 'old regionalism' aimed either at security alliance formation or at the building of trade blocs, new regionalism is a multi-dimensional phenomenon. The new regionalism is more likely to succeed if there is a strong market-led pressure for cooperation arising from the potential of economic gains from market exchanges. Importantly, old regionalism was a state-centric process, while new regionalism is a process that involves non-state actors at different levels. However, new regionalism is still concerned with states, and one may have to be careful of being overly optimistic about the capacity of regional organizations and institutions, as state power does not vanish, even when it loses some of its former preeminence. The focus of the new regionalism is more on economic aspects than on political ones, with an emphasis on complex, multi-layered relationships between public- and private-sector stakeholders. As a consequence, new regionalism provides the foundations of sub-regional development projects. The new regionalism's merit rests on its analytical power and applicability in researching contemporary sub-regional cooperation schemes [4, p. 257].

The notion of sub-regionalism can be considered an extension of the new regionalism, with the down-scaling of economic, political and social processes that has been occurring recently. Contemporary sub-regionalism represents a new pattern in international relations fostered by forces in the post-Cold War context of economic globalization [5, p. 45]. The term 'sub-regionalism' has frequently been used to imply low or limited cooperation between states engaged in a wider regional integration process. Relative to regional integration, sub-regionalism aims for integration within a more local context. Therefore, a distinct element of sub-regionalism is associated with its subordinate nature with respect to state-led decision-making. It is embedded in a more local but still transnational setting. Sub-regionalism may be promoted by weaker states that are seeking to strengthen cooperation in a more circumscribed space at local and sub-regional levels in the global political economy. As a result, domestic factors play an important role in the formation of sub-regional groups [6, p. 328]. Similar to the features of new regionalism, sub-regionalism involves multi-dimensionality, particularly activities to promote exports and trade liberalization. The increase of cross-border, trans-national production processes have contributed to the rise of sub-regionalism, which aims to connect economic activities in close proximity with economic complementarity across borders. 
Economic complementarity brings about trade between neighbours by reducing transport and communication costs. The main objective of sub-regional cooperation has been to encourage specific and limited linkages of complementary economic activities across borders. It does not need to involve entire countries, but simply adjacent areas within countries that have complementary capacities and resources across borders. Subregionalism emerges as a response to increased social and economic interdependence. Finally, sub-regionalism may focus on 'soft' security issues, such as organized crime, trafficking in humans, drugs, nuclear materials and weapons, environmental and health risks, and corruption. Sub-regional cooperation provides a politically low-cost, low-risk, localized and outward-oriented approach for countries sharing similar needs and objectives.

While the geographical scope of regionalism covers the whole state or inter-state connection, sub-regionalism involves sub-national provinces or lower-level areas with natural borders such as rivers or seas. Regionalism aims at formal institutional integration or a trade bloc, employing a top-down process. Sub-regionalism contains looser institutional forms, with either top-down, bottom-up, or a combination of both approaches with social and economic concerns. While regional integration is often more aware of security and political issues, sub-regionalism responds to the demand for transnational development, e.g. infrastructure, transport, environmental problems, natural resources and human contact. While sometimes, regionalism is influenced by hegemon state and dominant private sector organizations, sub-regionalism involves multiple layers of actors at many levels: national, provincial and local authorities, private business, civil society, and regional organizations with external funds.

\section{Background of GMS}

In 1992, the Greater Mekong Sub-region embarked on a programme of economic cooperation and sub-regional integration supported by the Asian Development Bank (ADB), which introduced a regional technical assistance programme designed to promote and facilitate economic cooperation between the six countries sharing the Mekong basin, namely the People's Republic of China (Yunnan province and Guangxi autonomous region), Cambodia, Lao PDR, Myanmar, Thailand and Vietnam. The GMS process begun as a pragmatic, activity-driven, and results-oriented initiative, which has turned out to be informal and guided only by a general set of principles and institutional arrangements. Key objectives were identified: to realise and enhance sub-regional development opportunities, with the main objectives to support trade and investment, to improve employment opportunities, generate higher living standards, reduce poverty, and modernize the various economic sectors. In addition, addressing or mitigating trans-border problems (such as diseases, drugs and environmental degradation), and exploiting common resources and policies are also goals to be addressed [7]. However, the principle focus of support is on developing the missing transport infrastructure within the sub-region, since establishing a sub-regional-wide transportation network is perceived as the key for supporting regional development. At the Third Ministerial Conference in 1994 [8], the six member countries endorsed eight priority sub-regional projects and initiatives: energy, environment, human resource development, transportation, telecommunications, tourism, trade, and investment. However, infrastructure development at the sub-regional level continues to be a critical aspect for supporting sub-regional integration, by creating a network between the 
population centres, tourist areas, and markets. It is recognised that supporting trade and transportation facilitation must also include an emphasis on non-physical measures, with the aim of encouraging cross-border and sub-regional trade through the simplification of border crossing procedures.

The first stage comprised the initial phase of the GMS programme from 1992 to 2002. It was under the 'Two Plus' principle and based on two conditions: (a) each sub-regional project may involve two countries or more, and (b) it may be a national project that will benefit the whole sub-region. It was aimed at enhancing the sub-regional cooperation in infrastructure development, such as road, rail, airport, power grid, tourism, and disease control. However, after the Asian financial crisis in 1997, it was agreed to adjust the GMS strategy by prioritizing the projects and allocating the capital, and by focusing more on cooperation within the 'software' aspect by improving the internal regulations of each country, especially in regard to trade and investment regulations and policies. It was also decided to create three economic corridors, based on the main sub-regional transportation networks, to support development.

Two potential economic corridors were identified, one East-West economic corridor (EWEC) to connect Vietnam, Laos and Thailand with Myanmar, and a North-South economic corridor (NSEC) linking China, Laos, and Myanmar with Thailand. The EWEC stretches from the port of Da Nang in Vietnam through Laos and Thailand to the port of Mawlamying in Myanmar. With a length of $1,450 \mathrm{~km}$, it is the longer of the two economic corridors. The second economic corridor, the NSEC, aims to connect China's Yunnan province with Southeast Asia through Myanmar, Laos and Thailand. As such, the NSEC also offers a vital link for China's southern landlocked Yunnan province by establishing a connection with the sea. According to Mr. Niyom Varairatpan and Mr. Iwasaki Hideaki, the EWEC represented not only a major land transportation route but also the only single route that links the Indian Ocean with the South China Sea ${ }^{1}$. The strategic plan of economic corridor development, outlined at the first GMS Summit held in 2002, is called the '3Cs' and consists of establishing a connection (Connectivity), competitive capacitybuilding (Competitiveness), and community building (Community). All projects involved focused on utilizing and improving existing infrastructure.

The economic corridor concept has also become an important issue for private business development in the Mekong River basin, especially focusing on road and bridge infrastructure, but also on generating a region-wide electricity network to secure general access to electricity. However, creating a sub-regional integrated market was a slow process during the first decades. According to Mr. Varairatpanich ${ }^{2}$, there were still problems with GMS cooperation in the first stage, such as barriers to investment, restrictions on capital movement, a deficit in cross-border cooperation, and little or no harmonisation of rules and regulations between the GMS member countries. These shortcomings undermined the economic growth potential in the Mekong River basin. Potential investors faced lack of human resource development, pressing environmental issues, and other challenges in the GMS area, thus discouraging foreign investment in the sub-region.

\footnotetext{
${ }^{1}$ Iwasaki Hideaki, Asian Development Bank's Country Director for Thailand and Nikom Warairatpanich, Thailand Chamber of Commerce. Personal interview, 2018.

${ }^{2}$ Niyom Varairatpanich, Vice Chairman of the Thai Chamber of Commerce as a President of Committee on Economic Cooperation with Neighboring Countries. Personal interview, 2018.
} 
The second phase of the GMS integration process was supported by the First Strategic Framework 2002-2012 (SF-I), agreed on at the first GMS summit in 2002 in Cambodia. At that meeting, SF-I was endorsed as the key concept through which closer economic cooperation and prosperity within the sub-region should be achieved, poverty reduced, and sustainable development promoted [9, p.2]. The first aim of SF-I is to improve physical connectivity in support of sub-regional cooperation in transport, energy, and telecommunications, as well as cooperation in agriculture to help ensure the full development benefits of the infrastructure investments $[9$, p.4]. At this stage, addressing software aspects, like the harmonisation of rules and regulations, was initially encouraged to complement hardware development (building of infrastructure). The GMS Cross Border Trade Facilitation Agreement (GMS CBTA) represents such a framework for facilitating trade and transportation within the sub-region. GMS economic corridors (the East-West, the North-South, and later the Southern Economic Corridor) became the top goal of the GMS [10]. In addition to focusing on policy and the institutional dimensions of infrastructure development, SF-I also had an increased emphasis on knowledge generation and the management-related aspects of initiatives, with a focus on cross-country coordination $[9$, p. 11].

Nevertheless, it was recognized that the development of economic corridors was a much more complex process, as the spatial planning dimension needed to be considered, in addition to changes and transformation in the social and economic structures of the involved countries. It was recognised that signing and implementing agreements between the GMS member states can be a slow and limited experience, such as the Cross-Border Transport agreement (CBTA), the Agreement on Power Trade, or the qualitative upgrading of transport corridors into economic corridors.

The third phase of the GMS development began with the Second Strategic Framework 2012-2022 (SF-II). The SF-II was adopted at the fourth GMS Summit in 2011 in order to (a) establish a closer link with the broader regional integration agenda, thus accelerating GMS's integration with the rest of Asia; (b) focus more effectively on the agreement and legal aspects to complement the continued focus on physical connectedness, such as infrastructure, and foster mobility; and (c) promote closer links within sectors for greater synergy. These moves would increase the involvement of multi-sector investment and cross-sectoral linkages and include more local stakeholders [9, p. 17-18].

According to the Summary of Preliminary Findings of the Mid-term Review of the GMS Strategic Framework 2012-2022 and on the Hanoi Action Plan 2018-2022, in order to achieve the goals set in the economic corridor approach, there is an ongoing requirement to focus on transport, trade facilitation and logistics to lower the transaction cost of trade within the sub-region [11]. Additionally, prioritizing road-rail transport cooperation will be part of a new emphasis on developing rail transport and the establishment of a sub-regional wide rail network by $2020^{3}$.

In sum, by 2017, in the first 25 years of the GMS process, the members were able to decide on the corridor approach and to implement the necessary improvements in hard infrastructure, parallel with improving related rules and regulations on soft infrastructure. The perceived weaknesses identified so far in the GMS are based on a variety of reasons, such as a lack of financial and technical support for some sectors; less-than-ef-

${ }^{3}$ Iwasaki Hideaki, Asian Development Bank's Country Director for Thailand and Nikom Warairatpanich, Thailand Chamber of Commerce. Personal interview, 2018. 
fective working groups; and weak monitoring and evaluation systems. For example, some of the less effective working groups/forums are identifiable within the transport, agriculture, and environment and tourism sectors. The Regional Power Trade Coordination Committee (RPTCC) and the Human Resource Development and Transport and Trade Facilitation are also performing below expectations. In addition, the Trade Facilitation Working Group (TFWG), Sub-regional Investment Working Group (SIWG), Sub-regional Telecommunications Forum (STF), and Sub-regional Energy Forum (SEF) have been inactive. Taken together, there is a clear need to revisit less effective working groups with the view to reactivating them or rationalizing their functions. Adding further voice to this weak 'performance review' are the results from the Preliminary Findings of the Mid-term Review of the GMS Strategic Framework 2012-2022 [12]. As for the special economic zone (SEZ) approach, while it offers an interesting route for reducing development and connectivity gaps, experience shows that it takes a long time to implement.

\section{Thailand's involvement in the GMS process}

\section{National support for sub-regional cooperation: Stakeholders, spatial development, and far eastern economic corridor in Thailand}

Thailand has played a very active role within the GMS integration process by taking economic leadership among the GMS countries. An important task is, therefore, to analyse how this engagement at the sub-regional level relates to Thai domestic politics, especially in relation to Thailand's own development strategies, and to discern what the implications are with regard to the GMS economic corridor and transport development. Such an enquiry is especially relevant for Thailand, considering that Thailand is the country most interested in promoting the development of economic corridors and the facilitation of cross-border economic activities with GMS members in order to increase economic and development opportunities in border areas and to facilitate a closer integration with neighbouring countries in terms of trade, investment, and tourism.

After GMS was established as a sub-regional focal point in 1992, sub-regionalism became one of the political-economic instruments of the involved countries to target specific underdeveloped areas, within their jurisdiction, for supporting domestic development. The Thai government also aimed to strengthen its relationship to other GMS member countries by supporting the emerging sub-regional integration process. From 1998, the Thai government started to reform its financial and foreign trade systems, upgrading international financial services, and investing in airports, harbours, roads, and telecommunications.

Policies regarding the GMS in Thailand were included in the eighth National Development Plan in $1992^{4}$. The thrust into the GMS space continued to be harmonized to facilitate trade and investment [13]. With the GMS policy, Thailand needed to cooperate with neighbouring countries and to make it consistent with the national strategic plan. At the same time, national development strategies also needed to be aligned with the ADB's GMS policies, such as its regional investment framework (RIF). The Thai government hoped that sub-regional cooperation integration processes would benefit Thailand

${ }^{4}$ Wuttidech Chamnikij and Dr. Piyanuch Wuttisorn, Office of the National Economics and Social Development Board. Personal interviews, 2018. 
through wider market access and a stronger collective voice in international fora. Within Thailand, the perception exists that its own success in economic development would also support neighbouring countries development process. Therefore, sub-regional cooperation is not only interpreted as an opportunity for expanding market and trade opportunities but also to narrow the economic gaps in the region [14].

Thailand has anticipated the benefits from a well-established sub-regional transport network, which would also serve domestic producers and develop a strong national market able to tackle the global market competition in order to facilitate foreign trade and foreign direct investment [15, p. 26]. Consequently, in the first five years of the GMS process (1992-1997), Thailand invested heavily in infrastructure to increase mobility of labour and goods with neighbouring states. Evidently, in order to promote sub-regional linkage, Thailand initiated domestic projects that dovetailed neatly with GMS projects and supported financial by the ADB. As pointed out by Battersby [16, p. 357], the most obviously important interconnection with the GMS is the network of four-lane highways fanning outwards from Bangkok and Thailand's Eastern Seaboard (ESB) to major centres in Laos, Vietnam, and China, complemented by the proposed Southern Seaboard Project (SSB) in 2016. Lastly, the Thai-Burma Seaboard Development Zone proposal aimed to develop additional land bridges from the Gulf of Thailand to proposed deep water ports at Thavoy (Thawai) and Mergui (Marit) in Burma. They are designed to draw shipping away from the congested Straits of Malacca, with the intent to capture a large share of the freight transhipment trade from Singapore and Penang in Malaysia [17, p. 480].

Another motivation for Thailand's cooperation in the GMS process is related to Thailand's increasing demands for natural resources as its own natural resource base has undergone considerable degradation during the past thirty years, as its economy has prospered. Considering the current critical level of resource degradation and depletion, it is questionable to what extent the needs of an increasing urban society and economy can be met by Thailand's own remaining resources. Of particular concern, from Thailand's point of view, are energy, water, and forest resources [18, p. 1]. The Thai government recognised the enormous resource potential of the Mekong region, which could not only support subregional development but Thailand's own development. Thailand's physical proximity and cultural links with the Mekong region and Southeast Asia not only offer raw material and cheap labour (Cambodia, Laos, Myanmar, Vietnam, and Brunei), but also a production base for various industries (Thailand, Philippines, Indonesia, and Malaysia) [19]. Likewise, a Ministry of Foreign Affairs statement, for example, depicted the Greater Mekong Sub- region by and large as a natural economic body, which is also home to people who have close cultural and historical linkages [20]. Such references are not only made to the economic potential of sub-regional cooperation but also to close relations based on ethnicity and a shared cultural identity among the GMS countries. In this way, the GMS sub-region bestows unique advantages in supporting Thailand's economic growth and competition with other regional rivals, such as Malaysia and Singapore.

In further consolidating its leading position, Thailand also wants to become a major source for financial support for the Cambodia, Laos, Myanmar and Vietnam (CLMV) countries by offering loans for infrastructure projects, such as high-speed rail links, twin rail construction, and airport development. To support development in neighbouring countries, Thailand set aside a budget of three trillion baht in 2003 and is also willing to 
share technical experiences in various fields ${ }^{5}$. The Neighbouring Countries Economic Development Cooperation Agency, or NEDA, is responsible for providing this development support, as Thailand recently underwent a comprehensive transformation at the regional level, to become an active donor in the Mekong region.

According to ADB's Procurement Guidelines, Thailand established Special Border Economic Zones (SBEZs) to promote economic development and higher levels of private investment in the provinces close to the Mekong area and continued to negotiate subregional free trade agreements ${ }^{6}$. In order to push forward the economic development of member countries, especially the development of their border economies, the Thai government established a number of infrastructure projects, such as the Mekong River Bridge from Nong Khai to Vientiane, the construction of the new Nong Khai railway station, and the construction of new Mekong River riparian ports, such as Chiang Saen and Chiang Khong ports, which were completed since 2013. Moreover, Thailand hopes to become the centre of navigation, transportation, finance, and the regional economy of Southeast Asia. It would also facilitate Thailand's goal to become the economic centre of Southeast Asia in 2020. Dr Surin Pittsuwan, Former Secretary-General of ASEAN in 2008-2012, also insisted that Thai government regarded GMS economic cooperation as an opportunity for Thailand's future economic development. It will form unique economic circles among the neighbouring countries and promote cooperation between their bordering provinces ${ }^{7}$.

This can also be seen from the support for the GMS SF-II framework (2012-2020), in which transport and trade facilitation are the most visibly successful projects. At the fifth GMS Summit in December 2014, Thailand expressed its interest in operationalizing SF-II further, including the corridor development strategy, through spatial and thematic support, such as multi-sector investment and cross-sectoral linkages, and by generating multiple local stakeholders' involvement. Based on the positive previous economic impact, the Regional Investment Framework (RIF) 2013-2022 was further reformulated in the 2014-2018 period. The first priority was given to transportation projects, while the second priority was placed on energy, tourism, and agriculture projects. However, the implementation of the transboundary goods agreement is currently not fully enforceable, because of Thai domestic law and missing international agreements with neighbouring countries on issues like customs transit regulations and visas for people or licenses for vehicles. After all, some trans-border issues remain based on bilateral agreements. Even so, from the Thai perspective, the implementation of the GMS Strategic Framework II is part of the execution of Thailand's $12^{\text {th }}$ National Economic and Social Development Plan (2017-2021), which is consistent with the strategy of the GMS and the RIF.

As the mid-term review of SF-II 2018 shows, significant progress of Economic Corridor Development has been made with regard to the three GMS priority economic corridors, namely the East-West, the North-South, and the Southern Economic Corridor, with $85 \%$ of the related road projects being either completed or near completion [21]. In addition, related tourism infrastructure projects within the GMS framework are also progressing well.

\footnotetext{
${ }^{5}$ Colonel Saranyu Viriyavejakul, Vice President of Neighbouring Counties Economic Development Cooperation Agency, Ministry of Finance of Thailand. Personal interview, 2018.

${ }^{6}$ A representative of Nation Building Economic Stimulus Plan (NBESP). Personal interview, 2018.

${ }^{7}$ Dr. Surin Pittsuwan, Former Secretary-General of ASEAN 2008-2012. Personal interview, 2017.
} 
Bilateral cooperation is interpreted as the key to enhancing economic relationships between Thailand and the GMS countries, in accordance with cooperation processes like GMS and the Ayeyawady - Chao Phraya - Mekong Economic Cooperation Strategy $\left(\mathrm{ACMECS}^{8}\right)$ to show that for the time being, the riparian countries in the Mekong Subregion have been able to do so under the leadership of Thailand under a military government ${ }^{9}$. As a consequence, the recent ACMECS summit held in June 2018 needs to reformulate the concept for how the CLMVT as a group could join hands to increase cooperation in all dimensions among the lower riparian countries, as well as serving as a bloc to create leverage against China, which is the world's No. 2 economic power as well as the No. 1 upper riparian country. In 2016, the ministers from the GMS countries approved changes in the configuration of the GMS economic corridors to ensure the following: (a) that there would be a close match between corridor routes and trade flows, (b) that GMS capitals and major urban centres would be connected to one another, and (c) that the corridors would be linked with maritime gateways. In addition, a new subcorridor was added to the North-South Economic Corridor linking Mandalay to Tamu at the border with India, with the aim of building transport links with South Asia. This is part of the India-Myanmar-Thailand Trilateral Highway Project linking India to Thailand through Myanmar.

On another positive note, there has been progress in implementing an early harvest measure for a Cross Border Trade Agreement, or CBTA. The GMS members agreed on the issuance of 500 cross-border licenses to vehicles in all six GMS member countries from 1 August $2018^{10}$. However, implementing it still requires bilateral agreements between each pair of countries, but it uses the same standard of documentation - the Temporary Admission Documents (TADs) - for goods and passenger vehicles, which represents an important step forward. The next step is to simplify and standardize the customs procedures of GMS members. However, it must not be in conflict with Thailand's own national development plan, and at the same time must be consistent with its policy of ongoing support for investments in neighbouring countries.

\section{The role of Thai stakeholders in GMS development}

The policy making and implementation of the GMS process in Thailand depend on central government actors and working groups that are based at a national contact point. For each working group, a cabinet decision is required to designate the principal agency in that working group. For example, the primary agencies for the transport working group are the Ministry of Transport and the Department of Land Transport. This agency will also provide opportunities for the private sector to attend meetings and listen to the opinions and suggestions of private stakeholders. The Thai Chamber of Commerce, the Federation of Thai Industries, and the United Overseas Bank are active in the Working

${ }^{8}$ ACMECS is a cooperation framework amongst Cambodia, Lao PDR, Myanmar, Thailand and Vietnam to utilize member countries' diverse strengths and to promote balanced development in the sub-region. Former Prime Minister Thaksin Shinawatra of Thailand initiated the establishment of this cooperation framework in April 2003.

${ }_{9}^{9}$ Kavi Chongkittavorn, Visiting Fellow at the East-West Centre in Washington, DC. Personal interview, 2018.

${ }^{10}$ Dollaya Panthanont, Transport Technical Officer, International Cooperation Bureau, Ministry of Transport, Thailand. Personal interview, 2018. 
Group on Transportation and the CBT. The central government represents Thailand in the government-to-government talks.

The private sector, particularly the Thai Chamber of Commerce, has played an important role in the GMS integration process since the establishment of the GMS in 1992. According to Mr. Warairatpanich, the President of the Committee on Economic Cooperation with Neighbouring Countries, support from the Thai Chamber of Commerce represents a key aspect of the planning. Dr Supachai Panitchpakdi, a former Deputy Prime Minister, entrusted with oversight of the country's economic and trade policy, aimed to facilitate economic cooperation under the Economic Quadrangle framework (LMVT) since $1992^{11}$. The Thai Chamber of Commerce has focused on border trade with neighbouring countries, especially the border trade in Chiang Rai via the Friendship Bridge across the Mae Sae River, from Mae Sai to Tachileik,Thailand. In addition, via road transport (on the R3B route), linking Thailand with Myanmar, Southern China and India. Mr Thanomsak Seree Vichayasawat, a former President of the Thai Chamber of Commerce, supported GMS initiatives because he sought a new framework for reinforcing border trade with neighbouring countries. His thought was analogous to that of Dr Supachai and the Secretary General of the NESDB, so they successfully proposed construction of the bridge at Mae Sai to the ADB under the framework of GMS Economic Cooperation.

Furthermore, the Thai Chamber of Commerce became a pioneer when it launched the Cross-Border Trade Agreement (CBTA) in 2009, which has contributed to the enforcement of border legislation to reduce the transit time ${ }^{12}$. Nevertheless, trade and economic policies are not equivalent across countries, so it is difficult to enforce all CBTA systems. For example, Myanmar wished to have a bilateral agreement with Thailand in logistics permits and customs clearance. In addition, at the same time, each country wished to preserve their national interest and was unwilling to lose existing commercial benefits if traffic was allowed to move freely across borders. There are also conflicts between Thai government agencies, as they were concerned that Thailand would lose benefits; all those obstacles led to the failure of the CBTA agreement. Additionally, the records of the Thai Chamber of Commerce show that the highest trade value in border towns of five provinces - Tak, Sa Kaeo, Nong Khai, Songkhla, and Mukdahan — for which a strategy of special economic zones (SEZs) was developed under GMS cooperation. SEZs can attract FDI and support the Thai Chamber of Commerce's efforts to bring development from the region to the city under the 'small town strategy', emphasizing border trade management, customs, transit permits, investments in the creation of warehouses, and logistics centres.

A special economic zone is an administrative area with tax incentives, low-cost labour, and access to land, including the granting of various exclusive rights under the legislative framework. Over time, SEZs have become an important tool for supporting economic development both within Thailand's border areas and at the sub-regional level. In the case of Thailand, additional internal factors - such as centralized policy planning, the deterioration of natural resources, and a rapid process of urban development in every region - facilitate a development strategy in which SEZ development takes a prominent role in supporting local economic development. Therefore, from a domestic perspective,

${ }^{11}$ Iwasaki Hideaki, Asian Development Bank's Country Director for Thailand and Nikom Warairatpanich, Thailand Chamber of Commerce. Personal interview, 2018.

${ }^{12}$ Niyom Varairatpanich, Vice Chairman of the Thai Chamber of Commerce as a President of Committee on Economic Cooperation with Neighboring Countries. Personal interview, 2018. 
an SEZ represents a major approach for supporting local and sub-regional economic development. With regard to GMS economic corridor development, in Thailand, the SEZ policy was first launched in 2015, based on the government's belief in the strong potential of the 10 selected areas to connect with neighbouring countries in terms of trade, economy and investment, especially along EWEC and NSEC ${ }^{13}$. An SEZ pilot phase has been applied in which, initially, five provinces - Tak, Mukdahan, Sa Kaeo, Trat, and Songkhla - would take part. This will be followed by a second phase, in which a further five provinces - Nong Khai, Narathiwat, Chiang Rai, Nakhon Phanom, and Kanchanaburi will participate.

Applying the SEZ concept was instrumental to stimulating FDI and an emerging subregional integrated market area. In addition, a concentration of production capacities, machinery, raw material, and labour within those SEZs will further support local economic development within the border areas. For these reasons, they are featured in the $11^{\text {th }}$ and $12^{\text {th }}$ National Economic and Social Development Plans and form the main policy approach of the Thai government with regard to ASEAN countries. Moreover, the special relevance of SEZs for national development - and in the cross-border and regional context for Thailand's future economic development - is also confirmed by Chamnikij and Wuttisorn ${ }^{14}$. Thai government policy on SEZs includes a number of specific goals:

a) strengthen border security by spreading the prosperity and minimizing the disparity of development;

b) enhance the competitiveness of the countries through the entry into the ASEAN Economic Community (10 members, including CLMVT), and contribute to regional prosperity by enhancing income levels and career opportunities, leading to the improvement of the quality of life and the lessening of regional inequalities;

c) develop provincial central cities to be liveable and safe; standardize environmental management process; and improve their public transportation systems;

d) sustainably develop new economic zones as Thailand's gateway to regional and world markets.

SEZs are important for both the GMS and Thai economies, as they are all located at border areas and are able to provide tools for investment in basic economic structures in those areas. Therefore, SEZ's offer a potential tool for the economic corridor concept and support Thailand in becoming a new production base connecting with the region. Nonetheless, missing in this framework for supporting the development of Thailand's border area within the GMS context is public participation. In particular, neither the social impact nor the environmental impact - or even potential negative impacts on the livelihood of the people - was considered in formulating this development strategy.

\section{Issues for GMS development in Thailand}

Although the Hanoi Action Plan was agreed during the sixth GMS Summit in March 2018, which supported the CBTA as a concrete framework, the Thai Chamber of Commerce deemed that it would be difficult to implement because of existing non-collective

\footnotetext{
${ }^{13}$ Wuttidech Chamnikij and Dr. Piyanuch Wuttisorn, Office of the National Economics and Social Development Board. Personal interviews, 2018.

${ }^{14}$ Ibid.
} 
interests and the lack of integration of the government agencies in each member country. The economic gaps and imbalances in their levels of development, as well as different political regimes, led to a kind of disinterested or detached cooperation. Examples include visa permits for entering a transit country and the value of taxation, just a few of the many obstacles to investment. In order to obtain more benefit from the GMS integration process, the Thai government must seriously apply the laws of their Special Economic Zone, especially the logistics law and investment privileges. Private sector organizations should have a stronger role to help civil officers, with their knowledge and experience in business $[1]^{15}$.

According to the interview with officers of the NESDB, the key problem of GMS is the lack of coordination between member countries [13 $]^{16}$. In addition, the national policies and administrative systems of the agencies differ in various ways, which causes delays. Another aspect is that different sectors within GMS countries cannot agree on certain issues, such as the adoption of the CBTA agreement (Thailand was the last country to sign, because interagency coordination within Thailand was hard to achieve, especially with regard to customs duties, as this would mean the loss of financial revenues). Moreover, the late signing of the CBTA from Thailand was also related to the delays in the signing of each agency. And even if it were already signed, and if there were laws and regulations that were already launched in each country, it would still be delayed and difficult to implement.

Moreover, worst of all, GMS does not have a central agency for coordinating the work, which creates problems and means that enforcement cannot be achieved. Some countries do not have adequate regulatory capacity. In addition, China still does not use CBTA because its trade is mainly by sea, while CBTA is relevant only to land transportation. Thailand, therefore, has a problem in preparing specific areas, such as Mae Sot in the North, for taking on the important role of sub-regional transport hubs.

Comparing the first ten years and the last ten years of GMS, it can be seen as that there have been tremendous infrastructure development projects, such as roads, energy, and more connection routes, as well as more concrete rules, such as CBTA. Thailand has a well-deserved reputation as a regional hub for transportation, so it will be able to benefit from the linking of GMS with ASEAN through the Master Plan of ASEAN Connectivity, to easily connect the Mekong countries to Malaysia, Singapore, and Indonesia, which will make the flow of trade and investment in Southeast Asia much more feasible than before. Moreover, Thailand's Office of the National Economics and Social Development Board would also monitor and evaluate GMS projects and report to the GMS Secretariat.

\section{Conclusion}

The study of developmental sub-regionalism in the Greater Mekong Sub-region, especially the impact of the initiative on Thailand (and vice-versa), points to the need for alternative ways of understanding borders - both in a geographical sense and as an element of economic cooperation. An examination of developmental sub-regionalism theory suggests that the development of sub-regional economic cooperation in the GMS is in line with the economic development plans shown in the $10^{\text {th }}, 11^{\text {th }}$, and $12^{\text {th }}$ national

${ }^{15}$ Kavi Chongkittavorn, Visiting Fellow at the East-West Centre in Washington, DC. Personal interview, 2018.

${ }^{16}$ Ibid. 
strategies of Thailand. The GMS is a cooperative effort by six countries with a total area of over 200 million $\mathrm{km}^{2}$ and with a combined population of about 250 million. The area is abundant with natural resources and is the centre of contact between South Asia, East Asia, and Southeast Asia. Economic cooperation can spread over a wide variety of collaborations: communication, transportation, energy, telecommunications, human resource development, tourism, environment and natural resource management, trade facilitation, investment, and agriculture.

At the beginning of the $21^{\text {st }}$ century, Thailand proposed to its mainland Southeast Asian neighbours another scope of cooperation, essentially with CLMV and Thailand, without the involvement of countries or organizations outside the group. Another major sub-regional economic cooperation initiative is the GMS, where Thailand also plays an active role, with the support of $\mathrm{ADB}$, for its links to the six countries involved within the framework.

As this study has shown, economic and trade activities in the 'GMS economic corridors' have helped to establish patterns of local development, such as special economic zones in Thailand. Sub-regional cooperation can create further economic and social development in border areas, especially if it is able to involve local provincial administrations and local businesses.

\section{References}

1. Asia-Europe Meeting Information Board (2015), $12^{\text {th }}$ ASEM Foreign Ministers' Meeting - Chair's Statement, November 5-6, available at: https://d333mq0i40sk06.cloudfront.net/documents/2015_-_ASEM_ FMM12_-_Chair_Statement_7P3dJOK.pdf (accessed: 20.11.2019).

2. Gamble, A. and Payne, A. (1996), Regionalism and World Order, Palgrave Macmillan, London, 296 p.

3. Waltz, S. M. (1986), Origins of Alliance, Cornell University Press, New York, 336 p.

4. Hook, G. and Kearns, I. (1999), Subregionalism and World Order, Palgrave Macmillan, London, 268 p..

5. Jessop, B. (2001), Poulantzas's State, Power, Socialism as a Modern Classic, Reading Poulantzas, eds Gallas, A., Bretthauer, L., Kannankulam, J. and Stutzle, I., Merlin, London, pp. 42-55.

6. Phillip, N. (2003), Reconfiguring Subregionalism: The Political Economy of Hemispheric Regionalism in the Americas, International Affairs, no. 79 (2), pp. 327-349.

7. Asian Development Bank (ADB) (2002), REG: Greater Mekong Subregion Economic Cooperation Program - Joint Summit Declaration: $1^{\text {st }}$ GMS Summit Leaders, November, available at: https://www.greatermekong.org/sites/default/files/1st-summit-joint-declaration-greater-mekong-subregion-gms.pdf (accessed: 20.11.2019).

8. Conference on Subregional Economic Cooperation and Asian Development Bank (1994), Economic cooperation in the greater Mekong subregion: Toward implementation: Proceedings of the Third Conference on Subregional Economic Cooperation among Cambodia, People's Republic of China, Lao People's Democratic Republic, Myanmar, Thailand and Viet Nam, Hanoi, Viet Nam, 20-23 April 1994. Manila, Philippines, Asian Development Bank. 406 p.

9. Asian Development Bank (ADB) (2011), The Greater Mekong Subregion Economic Cooperation Program Strategic Framework 2012-2022, Mandaluyong City, Philippines, available at: https://www.adb. $\mathrm{org} / \mathrm{sites} / \mathrm{default} /$ files/institutional-document/33422/files/gms-ec-framework-2012-2022.pdf (accessed: 20.11.2019).

10. Verbiest, J.-P. (2007), APCAC Annual Meeting at Ho Chi Minh City, Viet Nam on ADB in Regional Integration: The Case of the Greater Mekong Subregion, March 23, available at: http://36mfjx la0yt01ki78v3b b46n15gp.wpengine.netdna-cdn.com/wp-content/uploads/2014/03/070323-ADB-Presentation-GMS-J.P.Verbiest.pdf (accessed: 20.11.2019).

11. Greater Mekong Subregion Secretariat (GMS) (2017), Mid-Term Review of the GMS Strategies Framework 2012-2022, available at: https://www.greatermekong.org/sites/default/files/STF-21\%20-\%20Appendix\%207\%20GMS\%20MTR\%20\%28CNguyen\%29.pdf (accessed: 20.11.2019). 
12. Greater Mekong Subregion Secretariat (GMS) (2016), Mid-Term Review and Revised Regional Investment Framework Implementation Plan 2020, available at: https://www.greatermekong.org/sites/default/files/ gms-rif-ip-2020.pdf (accessed: 20.11.2019).

13. Snitwongse, K. (1993), Thailand in 1993: Politics of Survival, Asian Survey, no. 34 (2), pp. 147-152.

14. Funston, J. (1998), Thai Foreign Policy: Seeking Influence, Southeast Asian Affairs, pp. 292-306.

15. Siamwalla, A. (2002), The Evolving of the State, Private, and Local Actors in Rural Asia, Oxford University Press (China), Hong Kong, 190 p.

16. Battersby, P. (2014), Timetabling Globalization: Technology, Travel and Peripheral Integration, The SAGE Handbook of Globalization, eds Steger, M. B., Battersby P. and Siracusa, J. M., Sage Publications, Thousand Oaks, pp. 347-362.

17. Battersby, P. (1998), Border Politics and the Broader Politics of Thailand's International Relations in the 1990s: From Communism to Capitalism, Pacific Affairs, no. 71 (4), pp. 473-488.

18. Pednekar, S. (1995), NGOs and Natural Resources Management in Mainland Southeast Asia, TDRI Quarterly Review, no. 10 (3), pp. 21-27.

19. Chumchaivet, B. (2015), Indo-China: Golden Opportunity for AEC, Thairath Newspaper, May 11, available at: https://www.thairath.co.th/content/498040 (accessed: 20.11.2019). (In Thai)

20. Ministry of Foreign Affairs of the Kingdom of Thailand [Greater Mekong Sub-Region] (2003), available at: www.mfa.go.th (accessed: 01.11. 2003).

21. Office of the National Economic and Social Development Board, Office of the Prime Minister (2016), The Twelfth National Economic and Social Development Plan (201-2021), available at: http://www. nesdb.go.th/nesdb_en/ewt_w3c/ewt_dl_link.php?nid=4345 (accessed: 20.11.2019).

Received: November 18, 2019

Accepted: December 16, 2019

Author's information:

Ngampramuan Soavapa - Assistant Professor; soavapa@ru.ac.th 